\title{
PENGARUH BEKAM TERHADAP INTENSITAS NYERI PADA PENDERITA REMATIK DI WILAYAH KERJA PUSKESMAS TANJUNG HULU KECAMATAN PONTIANAK TIMUR KALIMANTAN BARAT
}

\author{
Ruhil Iswara $^{1 *}$, Lintang Sari ${ }^{2}$, Engkos Kosasih ${ }^{3}$ \\ 1.2.3 STIKes Yarsi Pontianak \\ Koresponden: \\ Ruhil Iswara : Program Studi Pendidikan Profesi Ners, STIKes Yarsi Pontianak \\ Jln Panglima A'im, No.1 Kota Pontianak, Kalimantan Barat - 78232, \\ E-mail: ruhiliswara@gmail.com
}

\begin{abstract}
ABSTRAK
Latar Belakang : Rematik merupakan keadaan progresif yang dimulai dengan rasa sakit dan kaku pada persendian yang dapat menyebabkan morbiditas dan kecacatan seumur hidup. Nyeri ini mengakibatkan penderita sulit untuk bergerak sehingga mengganggu aktivitas sehari-hari. Bekam merupakan pengobatan dengan penghisapan menggunakan cup pada kulit, kemudian darah dikeluarkan melalui sayatan bertujuan meningkatkan sirkulasi darah, menimbulkan efek penghilang nyeri, dan mengurangi pembengkakan. Tujuan Penelitian: Tujuan penelitian untuk mengetahui pengaruh terapi bekam terhadap intensitas nyeri pada penderita rematik. Jenis penelitian : Penelitian ini merupakan penelitian quasi experiment (eksperimen semu) dengan desain pre and posttest without control dengan responden sebanyak enam belas orang. Hasil penelitian : Perbedaan rata-rata skala nyeri sebelum dan setelah intervensi diuji menggunakan wilcoxon dengan hasil terdapat perbedaan yang bermakna pada rata-rata skala nyeri sebelum dan setelah intervensi dengan nilai $\mathrm{p}$ value $(0,001)<\alpha=0,05$. Dapat disimpulkan bahwa terapi bekam berpengaruh terhadap nyeri pada penderita rematik. Oleh karena itu disarankan kepada masyarakat untuk dapat memilih terapi bekam dalam mengurangi nyeri rematik.
\end{abstract}

Kata Kunci : Bekam, tulang dan sendi, reumatik

\section{ABSTRACT}

Background : Rheumatism is a progressive situation that starts pain and stiffness in the joints that can lead to morbidity and disability for life. This resulted in the patient pain is difficult to move so that interfere to daily activities. Cupping is a treatment by using a suction cup on the skin, then blood is removed through an incision aimed at increasing blood circulation, pain relief effect, and reduces swelling. Purpose : The aim of research was to determine the influence of cupping technic to pain intensity. Type of research : This research are a quasi-experimental, pre and post design without controlling group. The responden are sixteen people. Research results: The difference in average pain scale before and after the intervention were tested using wilcoxon with the result there is a significant difference in average pain scale before and after the intervention with $p$ value $(0.001)<\alpha=0,05$. It be conclude that the influence of cupping technic to pain intensity for rheumatic patient. Therefore it can be recommend to the public to choose cupping technic to decrease to pain of artritis.

Keywords: Cupping, Musculoskeletal, Pain, Rheumatism 


\section{PENDAHULUAN}

Penyakit rematik bukan penyakit yang mendapat sorotan seperti penyakit hipertensi, diabetes atau AIDS, namun penyakit ini menjadi masalah kesehatan yang cukup mengganggu dan terjadi dimana-mana. Rematik secara luas dapat dikategorikan sebagai penyakit sendi, kecacatan fisik, gangguan tulang belakang, dan kondisi yang disebabkan oleh trauma. Hal ini dapat menyebabkan morbiditas dan kecacatan seumur hidup, sehingga menimbulkan pengeluaran biaya kesehatan yang sangat besar dan hilangnya pekerjaan (WHO, 2014).

Istilah rematik sudah dikenal di masyarakat. Setiap ada keluhan pegalpegal, linu dan sakit persendian, maka dianggap sebagai sakit rematik. Sebenarnya rematik merupakan kumpulan dari gejala-gejala yang mempunyai tiga gejala utama, yaitu adanya pembengkakan sendi, kelemahan otot, dan gangguan gerak (Umar, 2012). Penyakit ini sangat progresif, apabila tidak diobati dengan benar maka dalam waktu singkat ( 2 tahun) akan terjadi cacat sendi permanen (Ulfah, 2009).

Penderita rematik di seluruh dunia telah mencapai angka 355 juta jiwa, artinya 1 dari 6 orang di dunia ini menderita rematik. Diperkirakan angka ini terus meningkat hingga tahun 2025 dengan indikasi lebih dari $25 \%$ akan mengalami kelumpuhan. Organisasi kesehatan dunia (WHO) melaporkan bahwa $20 \%$, penduduk dunia terserang penyakit arthritis rheumatoid. Dimana 5$10 \%$ adalah mereka yang berusia $5-20$ tahun dan $20 \%$ mereka yang berusia 55 tahun (Wiyono, 2010).

\section{Arthritis Foundation}

menerangkan bahwa jumlah penderita arthritis atau gangguan sendi kronis lain di Amerika Serikat terus meningkat. Pada tahun 1990 terdapat 38 juta penderita dari sebelumnya 35 juta pada tahun 1985. Data tahun 1998 memperlihatkan hampir 43 juta atau 1 dari 6 orang di Amerika menderita gangguan sendi, dan pada tahun 2005 jumlah penderita arthritis sudah mencapai 66 juta atau hampir 1 dari 3 orang menderita gangguan sendi.

Berdasarkan hasil studi pendahuluan di Dinas Kota Pontianak didapatkan angka kejadian rematik di Kota Pontianak pada tahun 2014 sebanyak 20.771 orang. Pada kota Pontianak didapatkan hasil bahwa wanita lebih banyak menderita rematik dibandingkan laki-laki dengan angka kejadian laki-laki sebanyak 7.317 orang (35,23\%) dan perempuan sebanyak 13.454 orang $(64,77 \%)$ (Dinkes. Kota Pontianak, 2014).

Data Puskesmas Tanjung Hulu Kec. Pontianak Timur pada bulan Februari 2015 didapatkan 55 orang menderita rematik. Kebanyakan dari penderita rematik ini melakukan pemeriksaan sebanyak 2-3 kali dalam sebulan. Pada bulan Februari didapatkan sebanyak 103 kunjungan dan merupakan penyakit peringkat kelima setelah penyakit infeksi, demam, gangguan fungsi tubuh dan hipertensi. Akibat yang timbulkan dari rasa nyeri ini dapat mengganggu aktifitas sehari-hari karena saat menggerakkan persendian yang mengalami rematik akan menimbulkan rasa nyeri meskipun telah diberikan obat.

Seiring dengan meningkatnya jumlah penduduk dunia maka jumlah penderita penyakit rematik secara otomatis akan meningkat pula. Namun dengan pengetahuan masyarakat saat ini yang masih kurang mengenai rematik dikhawatirkan akibat dari penyakit, yaitu kecacatan pun akan meningkat (Torich, 2011).

Semua jenis rematik menimbulkan rasa nyeri yang mengganggu. Biasanya nyeri ini disertai peradangan berupa pembengkakan setempat dan suhu yang tinggi dari pembengkakan tersebut. Dengan derita yang disandang itu, penderita rematik akan terganggu 
semangat kerjanya. Gangguan seperti susah berjalan, tidak dapat memegang gelas, tidak bisa berbalik, tidak bisa menyisir rambut, justru menjadi keluhan utama dari rasa nyeri itu sendiri. Gejala yang mengiringi rematik atau yang sering disebut nyeri rematik yaitu berkurangnya tenaga, rasa lelah, letih dan lemah (Wijayakusuma, 2007).

Nyeri merupakan suatu perasaan subjektif pribadi dan ambang toleransi nyeri berbeda-beda bagi setiap orang. Rasa nyeri dalam kebanyakan hal hanya merupakan suatu gejala yang berfungsi sebagai isyarat yang berfungsi sebagai isyarat bahaya tentang adanya gangguan di jaringan, seperti peradangan, infeksi jasad renik atau kejang otot (Tjay, 2007). Terlepas dari subjektivitasnya, perawat memiliki tanggung jawab untuk mengkaji secara akurat dan menolong meredakan atau menurunkan nyeri (Black \& Hawks, 2014: 441).

Penanganan untuk rematik dapat meliputi terapi farmakologis (obatobatan), nonfarmakologis dan tindakan operasi (American Collage Rheumatology dalam Purwoastuti, 2009). Sampai saat ini belum ada obat yang bisa menyembuhkan rematik secara tuntas. Obat yang diberikan hanya bertujuan untuk mengurangi rasa sakit, mencegah komplikasi, menghambat perjalanan rematik dan memaksimalkan fungsi tubuh (Umar, 2012).

Bekam merupakan pengobatan menggunakan cup yang ditelungkupkan pada kulit agar menimbulkan bendungan lokal. Kemudian darah dikeluarkan dengan hisapan bertujuan meningkatkan sirkulasi darah, menimbulkan efek penghilang nyeri, dan mengurangi pembengkakan (Umar, 2008). Rasulullah menyampaikan bahwa diantara pengobatan-pengobatan yang ada pada saat itu, bekam adalah pengobatan yang paling utama. Bahkan Rasulullah merekomendasikan umatnya agar berbekam (Umar, 2012).
Susiyanto (2003) dalam risetnya yang dilakukan selama 7 tahun mendapatkan hasil bahwa terapi bekam dapat menyembuhkan ribuan pasien dari penyakit ringan hingga penyakit berat (AIDS, kanker stadium 4, narkoba yang sudah parah, stroke, dan lain-lain). Riset Ullah (2007) juga menjelaskan terdapat perbedaan statistik yang signifikan dalam tingkat rasa sakit, kenyamanan dan rerata pergerakan pada pasien dengan nyeri lutut anterior antara sebelum dan setelah bekam.

Berdasarkan penjelasan di atas, rematik memiliki risiko yang besar sehingga dapat menyebabkan kecacatan seumur hidup sedangkan bekam memiliki manfaat yang sangat besar dalam kesehatan dan juga sebagai perindah dari nabi Muhammad SAW. Oleh karena itu peneliti merasa tertarik untuk melakukan penelitian ini untuk mengetahui pengaruh terapi bekam terhadap intensitas nyeri pada penderita rematik.

\section{METODE}

Penelitian ini merupakan penelitian quasi experiment (eksperimen semu) dengan desain pre and posttest without control yaitu dengan hanya melakukan intervensi pada satu kelompok tanpa pembanding. Penelitian ini dilakukan di wilayah kerja Puskesmas Tanjung Hulu.

Metode yang digunakan dalam pengambilan sampel pada penelitian ini adalah convinience sampling yaitu dengan memilih sampel berdasarkan keinginan peneliti tanpa sistematika tertentu. Dari 25 individu yang memenuhi kriteria, peneliti memilih 16 orang untuk dijadikan sebagai responden.

Penelitian ini menggunakan analisa data univariat untuk mengetahui karakteristik responden (umur dan jenis kelamin), skala nyeri sebelum dan sesudah 
dilakukan bekam. Data yang digunakan dalam penelitian ini merupakan data interval dan dilakukan uji beda mean dari 2 kelompok yang sama (pretest dan posttest). Dari hasil uji normalitas menunjukkan bahwa data berdistribusi tidak normal sehingga analisis data yang digunakan adalah Wilcoxon. Penelitian ini telah lolos kaji etik dengan nomor 208/BAAK/S.Y/VI/2015.

\section{HASIL}

1. Analisa Univariat

a. Karakteristik Responden Analisis data pada tabel di bawah ini menggambarkan distribusi karakteristik responden yang mengalami nyeri rematik meliputi umur responden dan intensitas nyeri sebelum dan sesudah dilakukan bekam.

Tabel 3.1

Distribusi Karakteristik Responden

Berdasarkan Umur, Intensitas nyeri

Sebelum dan Setelah Intervensi di

Wilayah Kerja Puskesmas Tanjung

Hulu Kec. Pontianak Timur Kalimantan Barat

\begin{tabular}{ccccc} 
Variabel & Mean & Median & SD & Min-Max \\
\hline Umur & 49,69 & 50,50 & 10,855 & $29-62$ \\
\hline $\begin{array}{c}\text { Intensitas nyeri penderita } \\
\text { rematik }\end{array}$ & 4,88 & 5,00 & 1,088 & $3-6$ \\
$\begin{array}{c}\text { sebelum intervensi } \\
\text { Intensitas nyeri penderita } \\
\begin{array}{c}\text { rematik } \\
\text { setelah intervensi }\end{array}\end{array}$ & 3,06 & 3,00 & 0,929 & $2-5$ \\
\hline Sumber: Data Primer, 2015 & & & & \\
\hline
\end{tabular}

Tabel di atas menggambarkan bahwa penelitian yang dilakukan di wilayah kerja Puskesmas Tanjung Hulu Kecamatan Pontianak Timur didapatkan rata-rata umur responden adalah 49,69 tahun, dengan umur termuda adalah 29 tahun dan yang tertua adalah 62 tahun.

$\begin{array}{lrr} & \text { Rata-rata } & \text { intensitas } \\ \text { nyeri } & \text { penderita } & \text { rematik } \\ \text { sebelum } & \text { dilakukan } & \text { bekam } \\ \text { adalah } 4,88 \text { (nyeri } & \text { sedang) } \\ \text { dengan } & \text { intensitas } & \text { nyeri } \\ \text { terendah } & \text { adalah } 3 & \text { dan yang } \\ \text { tertinggi } & \text { adalah } 6 . & \text { Setelah } \\ \text { dilakukan } \text { bekam } & \text { rata-rata } \\ \text { intensitas } & \text { nyeri menjadi } 3,06 \\ \text { (nyeri ringan), } & \text { dengan } \\ \text { intensitas nyeri } & \text { terendah } \\ \text { adalah 2 dan yang } & \text { tertinggi } \\ \text { adalah 5. } & & \end{array}$

b. Jenis Kelamin

Tabel 3.2

Distribusi Karakteristik Responden Berdasarkan Jenis Kelamin

di Wilayah Kerja Puskesmas Tanjung Hulu Kec. Pontianak Timur Kalimantan Barat

\begin{tabular}{cccc} 
No & Jenis Kelamin & Frekuensi & Persentase (\%) \\
\hline 1 & Laki-laki & 6 & $37,5 \%$ \\
\hline 2 & Perempuan & 10 & $62,5 \%$ \\
\hline & Jumlah & 16 & $100 \%$
\end{tabular}

Tabel di atas menggambarkan sebagian besar responden berjenis kelamin perempuan sebanyak 10 orang $(62,5 \%)$.

\section{Analisa Bivariat}

Skala data yang digunakan pada penelitian ini adalah adalah skala interval sehingga dilakukan uji normalitas distribusi data. Normalitas distribusi data diuji dengan uji shapiro-wilk dan didapatkan $\mathrm{p}<0,05$ sehingga data ini berdistribusi tidak normal. Selanjutnya kedua variabel ini dilakukan uji analisis dengan Wilcoxon. Hasil dari uji tersebut disajikan dalam tabel di bawah ini.

Tabel 3.3

Uji Wilcoxon Intensitas nyeri Pada Penderita Rematik Sebelum dan Setelah dilakukan Bekam 
Rata-rata intensitas nyeri pada penderita rematik sebelum dilakukan bekam adalah 5,00 dan termasuk dalam kategori nyeri sedang. Sedangkan rata-rata nyeri pada penderita rematik setelah 7 hari dilakukan bekam adalah 3,00 dan termasuk dalam kategori nyeri ringan.

Uji statistik dengan menggunakan uji Wilcoxon didapatkan bahwa nilai $\mathrm{p}<\alpha=0,05$ sehingga dapat disimpulkan ada perbedaan yang bermakna antara intensitas nyeri sebelum dan setelah dilakukan bekam.

\section{PEMBAHASAN}

1. Karakteristik Responden Hasil penelitian ini didapatkan rata-rata umur responden 49,69 tahun dengan umur termuda 29 tahun dan yang tertua 62 tahun. Angka kejadian paling banyak terjadi pada usia lansia akhir (56-65 tahun) yaitu 8 orang (50\%), selebihnya adalah pada kelompok usia dewasa akhir (36-45 tahun) yaitu 7 orang $(43,75)$ dan dewasa awal (26-35 tahun) 1 orang $(6,25 \%)$. Hasil ini sejalan dengan penelitian yang dilakukan Nainggolan pada tahun 2009 tentang prevalensi dan determinan penyakit rematik di Indonesia. Dalam penelitian ini didapat bahwa prevalensi penderita rematik yang paling banyak terdapat pada kelompok umur lebih dari 65 tahun sebesar $63,1 \%$ dan terlihat kecenderungan bahwa prevalensi akan semakin meningkat seiring dengan bertambahnya usia. Hal ini juga terjadi pada penelitian Suhendriyo (2014) dengan judul pengaruh senam rematik terhadap pengurangan rasa nyeri pada penderita Osteoatritis lutut di Karangasem Surakarta menunjukkan bahwa usia responden paling banyak

\begin{tabular}{clcc} 
Variabel & $\mathrm{N}$ & Median & P. Value \\
$\begin{array}{cccc}\text { Intensitas nyeri pada penderita } \\
\text { rematik }\end{array}$ & 16 & 5,00 & \\
\hline $\begin{array}{c}\text { sebelum intervensi } \\
\begin{array}{c}\text { Intensitas nyeri penderita pada } \\
\text { rematik }\end{array}\end{array}$ & 16 & 3,00 & \\
\end{tabular}

adalah lanjut usia $55-70$ tahun sejumlah 16 responden $(80 \%)$.

Seiring dengan bertambahnya umur semua organ tubuh mulai mengalami degenerasi. Degenerasi merupakan pengaruh genetik atau hormonal yang menyebabkan kegagalan perbaikan tulang rawan. Tulang rawan yang berfungsi menyediakan permukaan yang sangat halus dengan cairan sinovial untuk menghasilkan gesekan yang sangat rendah selama gerakan tidak mampu mentransmisikan beban atau tekanan tulang sehingga menimbulkan gesekan gerak sendi. Selanjutnya akan terjadi pembentukan tulang baru (osteofit) yang terbentuk di tepi permukaan sendi, sehingga menyebabkan ruang sendi menyempit, disertai dengan hilangnya stabilitas yang mengakibatkan sendi kaku dan nyeri (Smeltzer, et al., 2008: 1887).

Responden yang mengalami rematik pada penelitian ini sebagian besar berjenis kelamin perempuan $(62,5 \%)$. Hal ini menunjukkan bahwa perempuan memiliki resiko lebih tinggi terkena rematik. Hasil ini sejalan dengan penelitian yang dilakukan Nainggolan (2009) yang menunjukkan bahwa prevalensi rematik responden perempuan adalah $52,96 \%$, sedangkan prevalensi rematik laki-laki sebanyak 47,04\%. Hal ini juga sama pada penelitian Suhendriyo (2014) yang menunjukkan bahwa Jenis kelamin responden paling banyak adalah wanita sejumlah 17 orang (85\%). Fagositosis kompleks menyebabkan reaksi inflamasi (efusi sendi, nyeri, dan edema). Fagositosis 
menghasilkan bahan kimia seperti leukotrien dan prostaglandin. Leukotrien dan prostaglandin menghasilkan enzim seperti kolagenase yang memecah kolagen, bagian penting dari sendi yang normal. Pelepasan enzim ini dalam sendi menyebabkan edema, proliferasi membran sinovial dan pembentukan pannus, kerusakan tulang rawan, dan erosi tulang (Smeltzer, et al., 2008: 1887).

2. Pengaruh bekam terhadap nyeri pada penderita rematik

Hasil analisis statistik menunjukkan terdapat perbedaan yang bermakna antara intensitas nyeri sebelum dan setelah dilakukan bekam. Oleh karena itu dapat disimpulkan bahwa bekam berpengaruh terhadap intensitas nyeri pada penderita rematik.

Hasil ini sejalan dengan penelitian yang dilakukan oleh Suardana, dkk pada tahun 2012 tentang terapi bekam kering terhadap penurunan nyeri pada pasien dengan nyeri kepala primer. Pada penelitian tersebut didapatkan hasil bahwa sebagian besar responden sebelum diberikan terapi bekam kering mengeluh nyeri skala 7 (nyeri berat) dan setelah diberi terapi bekam kering adalah 4 (nyeri sedang). Pada penelitian selanjutnya yang dilakukan oleh Samiasih (2013) dengan judul bekam basah meningkatkan kualitas hidup sosial homaniora pasien migren didapatkan hasil Rata-rata gangguan ADL pasien Migren sebelum dilakukan bekam 73.40dan rata-rata gangguan ADL pasien Migren 1 minggu setelah dilakukan bekam 52.67. Penurunn intensitas nyeri juga terjadi pada penelitian Ullah (2007) tentang pengaruh terapi bekam untuk penanganan nyeri lutut anterior (bagian depan) dan potensi peranannya dalam promosi kesehatan menunjukkan adanya pengurangan rasa nyeri dan peningkatan kenyamanan yang bermakna.

Rematik

merupakan gangguan muskuloskeletal dengan keluhan rasa nyeri pada daerah persendian. Proses utama yang berperan dalam rematik adalah peradangan yang disebabkan oleh respon imun (Smelzer et al, 2008: 1887). Sampai saat ini belum didapatkan pengobatan yang bisa menyembuhkan rematik secara tuntas, dalam arti tidak kambuh lagi. Oleh karena itu pengobatan rematik ditujukan untuk menghilangkan nyeri dengan cara menekan proses peradangannya (Umar, 2012: 106107).

\begin{tabular}{lrr}
\multicolumn{2}{c}{ Sedangkan } & golongan \\
histamin yang & ditimbulkan \\
mempunyai & manfaat & dalam proses
\end{tabular} reparasi (perbaikan) sel, jaringan rusak dan memacu pembentukan reticulo endothelial cell, yang akan meninggikan daya resistensi (daya tahan) dan imunitas (kekebalan) tubuh. Sistem imun ini terjadi melalui pembentukan interleukin dari cell karena faktor neural, peningkatan jumlah sel $\mathrm{T}$ karena peningkatan set-enkephalin, enkephalin dan endorphin yang merupakan mediator antara susunan saraf pusat dan sistem imun, substansi $\mathrm{P}$ yang mempunyai fungsi parasimpatis dan sistem imun, serta peranan kelenjar pituitary dan hypothalamus anterior yang memproduksi CRF (Umar, 2012: 13).

Proses penghisapan kulit akan diikuti dengan pengumpulan jaringan bawah kulit dan darah dengan segala komponen yang ada dibawah kulit. Penghisapan akan meransang syaraf-syaraf pada permukaan kulit. Ransangan ini akan dilanjutkan pada cornu posterior medulla spinalis melalui syaraf Adelta dan $\mathrm{C}$, serta traktus spino thalamikus ke aras thalamus yang akan menghasilkan endorphin. 
Sedangkan sebagian ransangan akan diteruskan melalui serabut aferen simpatik menuju ke motor neuron dan menimbulkan refleks intubasi simpatis, sehingga menimbulkan intubasi nyeri secara general melalui endorphin dan segmental simpatis (Umar, 2008: 65).

\section{KESIMPULAN}

Berdasarkan hasil penelitian dan pembahasan tentang pengaruh bekam terhadap nyeri pada penderita rematik di wilayah kerja Puskesmas Tanjung Hulu Kec. Pontianak Timur Kalimantan Barat, dapat disimpulkan bahwa:

1. Rematik paling banyak terjadi pada usia lansia akhir (56-65 tahun) yaitu 8 orang $(50 \%)$ dan rematik juga lebih banyak terjadi pada wanita yaitu sebanyak 10 orang $(62,5 \%)$.

2. Rata-rata intensitas nyeri sebelum dilakukan bekam adalah 4,88 (nyeri sedang) dan rata-rata intensitas nyeri setelah dilakukan bekam mengalami penurunan menjadi 3,06 (nyeri ringan).

3. Terdapat perbedaan yang bermakna antara intensitas nyeri sebelum dilakukan bekam dan setelah dilakukan bekam ( $p$ value $<0,05$ ).

4. Bekam berpengaruh terhadap intensitas nyeri pada penderita rematik di wilayah kerja Puskesmas Tanjung Hulu Kec. Pontianak Timur Kalimantan Barat.

\section{UCAPAN TERIMA KASIH}

Dalam kesempatan ini saya akan menyampaikan terima kasih banyak kepada :

1. Kepada orang tua tercinta yang telah banyak berkorban tanpa lelah untuk memberikan support moral, moril dan material.
2. Ketua STIKes Yarsi Pontianak yang telah memfasilitasi saya selama penelitian

3. Kepada pembimbing pertama dan kedua saya yang telah banyak memberikan masukan dan saran sehingga saya bisa di titik ini.

4. Kepada teman-teman satu Angkatan yang luar biasa memberikan semangat dan support system selama penelitian.

5. Dan kepada responden yang telah bersedia untuk menjadi responden pada penelitian ini.

\section{REFERENSI}

Arthritis Foundation. (2006). The Facts About Arthritis. North Carolina: Arthritis Foundation.

Black, Joyce M., Hawks, Jane Hokanson. (2014). Keperawatan Medikal Bedah. Singapura: Elsevier.

Samiasih, Amin. (2013). Bekam Basah Meningkatkan Kualitas hidup Sosial Homaniora Pasien Migren. Jurnal Keperawatn Medikal Bedah; Vol. 1, No.2.

Smeltzer, Suzanne C., et al. (2008). Brunner \& Suddarth's Texktbook of Medical Surgical Nursing. United States America: Lippincott Williams \& Wilkins.

Suhendriyo. (2014). Pengaruh Senam Rematik Terhadap Pengurangan Rasa Nyeri Pada Penderita Osteoatritis Lutut di Karangasem Surakarta. Jurnal Teradi Ilmu Kesehatan; Volume 3, No 1.

Ulfah, Nurul. (2009). Rhematoid Artritis yang Misterius. (http://health.detik.com/read/2009/07/31 /130027/1175044/763/rheumatoidarthritis-yang-misterius didapat pada 2911-2014).

Ullah, Kaleem., Younis, Ahmed \& Wali, Mohamed. (2007). An investigation into 
the effect of Cupping Therapy as a treatment for Anterior Knee Pain and its potential role in Health Promotion. The Internet Journal of Alternative Medicine; Volume 4, Number 1.

Umar, Wadda' A. (2008). Sembuh dengan 1 titik. Solo: Al-Qowam.

Umar, Wadda' A. (2012). Bekam untuk 7 Penyakit Kronis. Solo: Thibbi. 